\title{
NITROGEN, POTASSIUM AND PHOSPHOROUS FERTILIZER SUGGESTIONS FOR AUSTRALIAN RED CEDAR IN OXISOL
}

\author{
Bruno da Silva Moretti ${ }^{1 *}$, Antonio Eduardo Furtini Neto $^{2}$, Bruno Peres Benatti ${ }^{3}$, Soami Deccetti ${ }^{1}$, \\ Julian Junio de Jesus Lacerda ${ }^{4}$, Eduardo de Castro Stehling ${ }^{5}$ \\ 1*Federal University of Lavras, Lavras, Minas Gerais, Brasil - bsmoretti@ hotmail.com; deccetti@yahoo.com.br \\ ${ }^{2}$ Vale Technological Institute, Belém, Pará, Brasil - furtinineto@gmail.com \\ ${ }^{3}$ Uralchem, Lavras, Minas Gerais, Brasil - brunopbenatti@ hotmail.com \\ ${ }^{4}$ Federal University of Piauí, Bom Jesus, Piaui, Brasil - julianlacerda@ hotamil.com \\ ${ }^{5}$ Viveiro Bela Vista Florestal, Campo Belo, Minas Gerais, Brasil - pesquisa @ belavistaflorestal.com.br
}

Recebido para publicação: 26/06/2014 - Aceito para publicação: 14/05/2015

\begin{abstract}
Forest species present around $75 \%$ of their nutrient demand in the initial growth stage. The objectives of this study were: to determine appropriate doses of N, P and K to be applied for Australian cedar cultivation in Oxisols; and to establish foliar contents suitable for the initial stage of plant development. Three concomitant experiments were carried out using randomized blocks design with four replications. In the first, it was provided 5 doses of $\mathrm{N}$, and in the second 5 doses of $\mathrm{P}_{2} \mathrm{O}_{5}$, and in the third 5 doses of $\mathrm{K}_{2} \mathrm{O}$. In all three experiments, Australian cedar seedlings were planted at $3 \times 2 \mathrm{~m}$ spacing. Maximum economic yield (MEY) was achieved when was provided $75 \mathrm{~g} \mathrm{~N}$, and $80 \mathrm{~g} \mathrm{P}_{2} \mathrm{O}_{5}$ per planting hole. In this study, could not be established the dose of $\mathrm{K}_{2} \mathrm{O}$ that allows MEY, because there was no difference in height and diameter of plants as a function of potassium fertilizer rates. The initial $\mathrm{K}$ concentration in the soil (around $100 \mathrm{mg} \cdot \mathrm{dm}^{-3}$ ) seems adequate to meet the nutritional needs to Australian cedar seedlings. Foliar concentrations did not vary with levels of $\mathrm{N}_{2} \mathrm{P}_{2} \mathrm{O}_{5}$ and $\mathrm{K}_{2} \mathrm{O}$ applied to soil. Mean content of N, P and K in the leaves of Australian cedar seedlings were 30, 18 and $2 \mathrm{mg} \cdot \mathrm{kg}^{-1}$, respectively.

Keywords: Mineral nutrition; silviculture; Toona ciliata.
\end{abstract}

\section{Resumo}

Sugestões de adubação nitrogenada, potássica e fosfatada para o cedro-australiano em Latossolos. Espécies florestais apresentam cerca de $75 \%$ de sua demanda de nutrientes na fase inicial de crescimento. Os objetivos deste estudo foram determinar doses adequadas de N, P e K a serem aplicadas para o cultivo de cedro-australiano em Latossolos e estabelecer os teores foliares adequados para a fase inicial de desenvolvimento da planta. Foram realizados três experimentos concomitantes, em que se aplicaram cinco doses de $\mathrm{N}$ no primeiro, cinco doses de $\mathrm{P}_{2} \mathrm{O}_{5}$ no segundo e cinco doses de $\mathrm{K}_{2} \mathrm{O}$ no terceiro. As mudas foram plantadas no espaçamento de $3 \times 2 \mathrm{~m}$, no delineamento experimental em blocos casualizados, com quatro repetições. A máxima eficiência econômica (MEY) foi alcançada com a oferta de $75 \mathrm{~g}$ de $\mathrm{N}$ e $80 \mathrm{~g}$ de $\mathrm{P}_{2} \mathrm{O}_{5}$ por cova de plantio. Para potássio, não foi possível estabelecer a dose que permite MEY, porque não houve diferença de altura e diâmetro das plantas que receberam doses diferentes do elemento. Portanto, a concentração inicial de K no solo (cerca de $100 \mathrm{mg} . \mathrm{dm}^{-3}$ ) parece ser adequada para satisfazer as necessidades nutricionais da espécie. $\mathrm{O}$ teor dos nutrientes nas folhas não variou com os níveis de $\mathrm{N}, \mathrm{P}_{2} \mathrm{O}_{5}$ e $\mathrm{K}_{2} \mathrm{O}$ aplicados no solo, e os níveis médios de $\mathrm{N}$, $\mathrm{P}$ e $\mathrm{K}$ nas folhas de cedro-australiano foram de 30,18 e $2 \mathrm{mg} . \mathrm{kg}^{-1}$, respectivamente.

Palavras-chave: Nutrição mineral; silvicultura; Toona ciliata.

\section{INTRODUCTION}

There has been increasing demand for timber, but at same time, constant pressure for the protection of native forests, so forestry companies have sought new alternatives to avoid the cutting of native species. In Brazil, the introduction of Australian cedar occurred especially in the Cerrado biome,

FLORESTA, Curitiba, PR, v. 45, n. 3, p. 599 - 608, jul. / set. 2015.

Moretti, B. da S. et al.

ISSN eletrônico 1982-4688 / ISSN impresso 0015-3826 
which is characterized by extensive areas of highly weathered and acidic soils, and for this reason with low natural fertility.

In this context, the Australian cedar (Toona ciliata var. Australis) has shown promise for commercial exploitation by presenting rapid growth, high productivity, and high quality of wood for furniture industry, similar to mahogany. Being a newly introduced species in the country, in-depth information on the nutritional requirements of Australian cedar are lacking, thereby the management has been done based on other species, such as eucalyptus. Therefore, scientific studies that provide a technical basis for planning appropriate input, especially for better efficiency use of fertilizers, in order to maximize yield and profits, to avoid waste and to minimize environmental risk are needed.

In general, forest species have high demand for nutrients in the early growth stage, around 70$80 \%$ in the first four years after planting (SANTANA et al. 2008). The hypothesis of this study is that Australian cedar plants that receive adequate amounts of fertilizer in the initial stage can develop in less time and are more productive than those under nutritional deficiency.

The objectives of this study were: a) to determine adequate doses of $\mathrm{N}, \mathrm{P}$ and $\mathrm{K}$ to be applied in Oxisols for the Australian cedar cultivation; b) to determine adequate foliar N, P and K content for initial stage of plant development; c) to evaluate growth in height and diameter of Australian cedar plants under supply of different fertilizer doses during the first year of cultivation.

\section{MATERIAL AND METHODS}

This study was carried out under field conditions, on the Bela Vista Farm in Campo Belo, Minas Gerais State, Brazil (20 $53^{\prime} 50^{\prime \prime} \mathrm{S}, 45^{\circ} 16^{\prime} 38^{\prime \prime} \mathrm{W}$ and $945 \mathrm{~m}$ altitude). The climate is classified as a CWA, in the Köppen system; with dry winters and means of annual precipitation and temperature equal 1530 $\mathrm{mm}$ and $19.4^{\circ} \mathrm{C}$, respectively.

Before the implementation of the experiments, soil samples were collected for chemical characterization and analyzed according to the EMBRAPA methodology (SILVA, 2009) (Table 1). The soil was classified as Red-Yellow Latosol (RYL) (Oxisol), with clayey texture.

Table 1. Chemical attributes of the Oxisol before treatments application.

Tabela 1. Atributos químicos do Latossolo antes da aplicação dos tratamentos.

\begin{tabular}{|c|c|c|c|c|c|c|c|c|}
\hline Layer & $\mathrm{pH} \mathrm{H}_{2} \mathrm{O}$ & \multicolumn{3}{|c|}{ mg.dm ${ }^{-3}$} & $\mathrm{Ca}^{2+}$ & $\mathbf{M g}^{2+}$ & cmol.dm ${ }^{-3}$ & $\mathbf{H}^{+}+\mathbf{A l}^{3+}$ \\
\hline $0-20$ & 5.2 & 10.7 & 117 & & 2.0 & 0.5 & 0.2 & 4.0 \\
\hline $20-40$ & 5.4 & 1.5 & 84 & & 1.4 & 0.3 & 0.2 & 2.6 \\
\hline & $\begin{array}{c}\text { OM } \\
\text { dag.dm } \\
\text { dag. }\end{array}$ & SB & $\begin{array}{c}\mathrm{t} \\
\text { cmol.d }\end{array}$ & $T$ & $\mathbf{V}$ & $\mathbf{m}$ & & $\begin{array}{l}\text { P-rem } \\
\text { mg.dm }\end{array}$ \\
\hline $0-20$ & 1.6 & 2.8 & 3.0 & 6.8 & 40.9 & 6.7 & & 38.6 \\
\hline $20-40$ & 1.0 & 1.9 & 2.1 & 4.5 & 42.5 & 9.5 & & 33.0 \\
\hline & \multicolumn{7}{|c|}{ mg.dm ${ }^{-3}$} & $\mathbf{S}$ \\
\hline $0-20$ & 1.9 & 32 & & 11.0 & 1.7 & & 0.5 & 22.1 \\
\hline $20-40$ & 1.2 & 30 & & 8.0 & 1.2 & & 0.2 & 17.0 \\
\hline
\end{tabular}

Three simultaneous and distinct experiments were carried out using an Australian cedar clone. The experimental design used in all three experiments was randomized blocks design with four replications. Each plot consisted of three rows planted with six plants in each row. The two lateral lines and the first and the last plant of each central row were maintained as a boundary, resulting in four useful plants in each plot. The seedlings were planted using $3 \times 2 \mathrm{~m}$ spacing.

The treatments consisted to apply: five $\mathrm{N}$ doses $(0,31,63,125,250 \mathrm{~g}$ hole- 1$)$ and fixed doses of $\mathrm{P}$ e K (63 g hole- 1 of $\mathrm{P}_{2} \mathrm{O}_{5}$ and $31 \mathrm{~g}$ hole- 1 of $\mathrm{K}_{2} \mathrm{O}$ ) in experiment 1 ; five doses of $\mathrm{P}_{2} \mathrm{O}_{5}(0,31,63,125$, $250 \mathrm{~g}$ hole-1) and fixed doses of $\mathrm{N}$ and $\mathrm{K}\left(63 \mathrm{~g}\right.$ hole- 1 of $\mathrm{N}$ and $31 \mathrm{~g}$ hole- 1 of $\left.\mathrm{K}_{2} \mathrm{O}\right)$ in the experiment 2; and five doses of $\mathrm{K}_{2} \mathrm{O}(0,16,31,63125 \mathrm{~g}$ hole -1$)$ and fixed doses of $\mathrm{N}$ and $\mathrm{P}(63 \mathrm{~g}$ hole- 1 of $\mathrm{N}$ and $63 \mathrm{~g}$ hole-1 of $\mathrm{P}_{2} \mathrm{O}_{5}$ ) in the experiment 3 . Micronutrients were not provided in these experiments, because 
initial contents in the soil were interpreted as adequate to major of cultivated plants in Minas Gerais State (ALVAREZ et al., 1999).

The fertilizers sources of nutrients used in all three experiments were: single superphosphate (SSP) with $18 \% \mathrm{P}_{2} \mathrm{O}_{5}$, potassium chloride $(\mathrm{KCl})$ with $60 \% \mathrm{~K}_{2} \mathrm{O}$ and urea with $45 \% \mathrm{~N}$. For greater agronomic efficiency, the SSP was applied in two small holes lateral to the plants. Urea and $\mathrm{KCl}$ were applied to the surface around the plant and at a radius of 25 centimeters from the stem. Fertilizations with $\mathrm{N}$ and $\mathrm{K}$ were split and performed at 20-day intervals.

During the experimental period, height and diameter values of plants were measured at five times: $60,80,126,171,219,305$ and 379 days after seedlings transplanting. On the 6th assessment (305 days) we collected leaflets for tissue analysis of $\mathrm{N}, \mathrm{P}$ or $\mathrm{K}$ in all three experiments.

For chemical analysis, the collected leaflets were washed using distilled water, and then they were oven-dried with forced air circulation at $65^{\circ} \mathrm{C}$ until constant weight. Subsequently, the leaflets were ground to determine total content of N, P and K. Analyzes were performed at Soil Science Department of Federal University of Lavras (UFLA), following methodology described by Malavolta et al. (1997).

In Experiment 1, to verify the influence of nitrogen fertilization on the anatomical characteristics of Australian cedar, 8 physiologically mature leaflets were collected from four plants grown without fertilizer, and from 8 plants that receiving application of $252 \mathrm{~g}$ of $\mathrm{N}$ per hole. Immediately after sampling, the leaves were fixed in formaldehyde, acetic acid and ethyl alcohol (FAA), in the ratio of 1:1:8, respectively, for 48 hours. After this period, the material was kept in $70 \%$ alcohol until the anatomical evaluations. Cuts were made freehand, and slides were prepared using glycerinated water. The leaf sections were stained with Safra-Blau and observed under light microscope and photographed.

Regression models were adjusted, when found significant $F$ value at 0.05 by variance analysis between treatments in each experiment. The models related height and collar diameter of the Australian cedar plants as a function of nitrogen, phosphorus and potassium rates applied. Statistical analysis was performed using statistical software Sisvar (FERREIRA, 2011). From the equations adjusted, maximum yield (MY) and maximum economic yield (MEY) were calculated, this last, corresponds to $90 \%$ of the MY (TUCCI et al. 2009).

\section{RESULT AND DISCUSSION}

\section{Experiment 1: Nitrogen dose variation}

The amount of nitrogen applied influenced the height and diameter of the Australian cedar seedlings. There was difference in plants height that received different $\mathrm{N}$ doses from the 5th up to 7th assessment (219 to 379 days after transplanting). It was found that Australian cedar had a low growth rate period $(<1.0 \mathrm{~cm}$ day-1) in the first three months after transplanting (Figure 1), probably because the seedlings were adaptation process in environmental conditions.

There was the close relationship between growth height of the Australian cedar seedlings and rainfall occurrence throughout the year (Figure 1).

Australian cedar growth rate was greater during higher rainfall period and high temperature (approximately November to March) than in the low rainfall period. From the first to the fourth assessments (60 to 171 days after transplanting), the plants showed slower growth compared with the other evaluations. In the second half of the trial period, the plants grew up about 3/4 of the size measured in the last evaluation (379 days after transplant) (Figure 1). These results indicate that it is necessary to provide nutrients especially when water is available, one can note, that the growth rate increased from the fourth to seventh assessment (171 to 379 days after transplanting), when the rain began to intensify.

From the fifth assessment (219 days after transplanting) it was possible to model Australian cedar growth as a function of the nitrogen applied. Linear model was appropriate to explain plants growth at 219 after transplanting, since increasing $\mathrm{N}$ rate there was proportional growth of the Australian cedar (Figure 2).

In subsequent evaluations (305 and 379 days after transplanting) the quadratic model was selected to represent the growth height of plants. This behavior can be explained by the "law of diminishing returns", because when the input (fertilizer) was added in production, the output (growth in height and diameter) was increased at an increasing rate, then at a decreasing rate, and finally declined. This indicates that nitrogen amount required is less than the highest dose applied in this experiment.

FLORESTA, Curitiba, PR, v. 45, n. 3, p. 599 - 608, jul. / set. 2015.

Moretti, B. da S. et al.

ISSN eletrônico 1982-4688 / ISSN impresso 0015-3826

601

DOI: $10.5380 /$ rf.v45i3.36554 
Furthermore, those plants could absorb nitrogen over their needs for growth as a luxury consumption of nutrient (LOPES; GUILHERME, 2000).
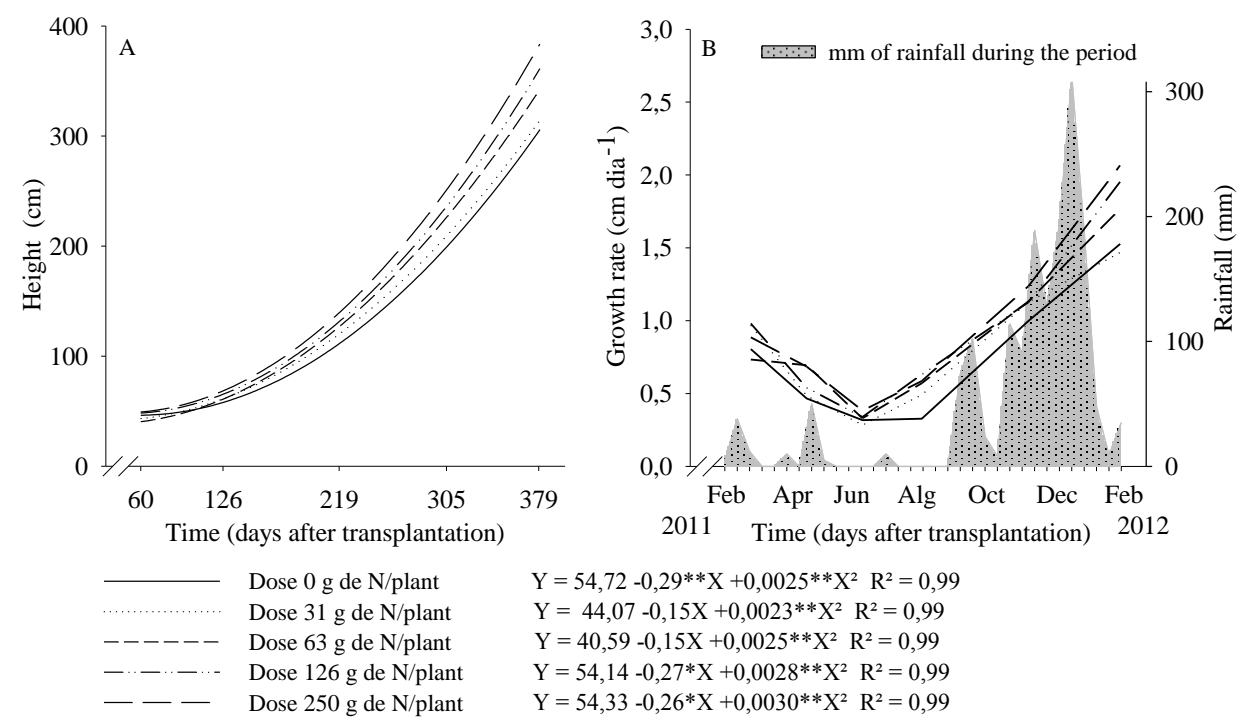

Figure 1. Plants height (A) and height growth rate (B) of Australian cedar as a function of time after transplanting (from 60 to 379 day) in each $\mathrm{N}$ dose applied.

Figura 1. Altura das plantas (A) e taxa de crescimento em altura (B) do cedro-australiano em função do tempo após o transplante (de 60 a 379 dias) em cada dose de $\mathrm{N}$ aplicada.
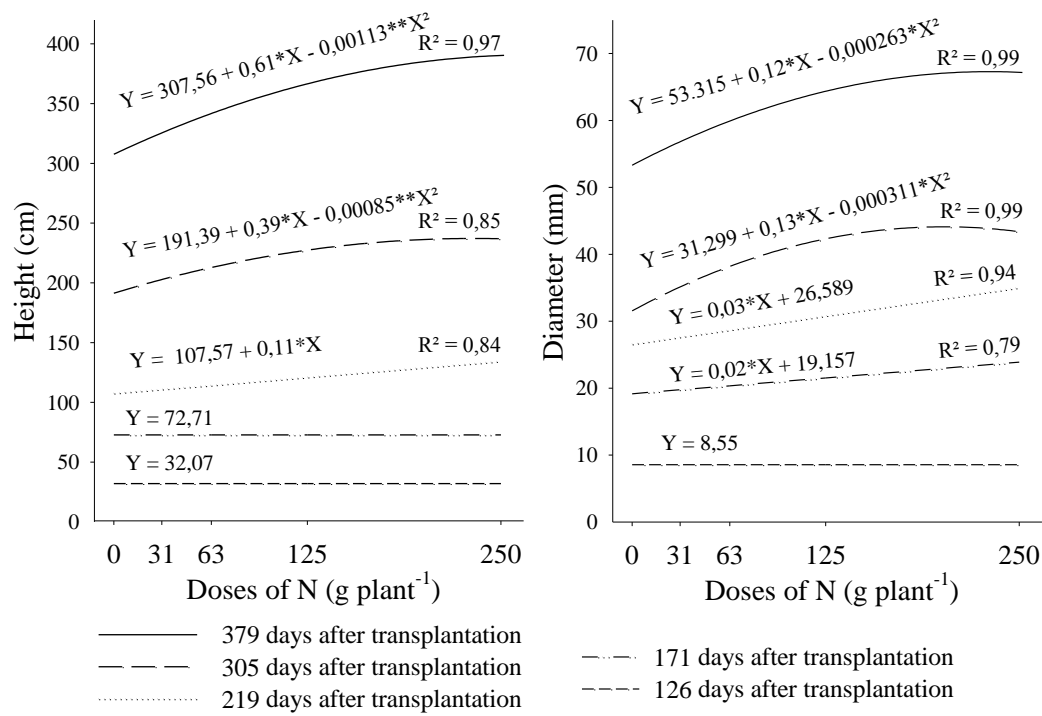

Figure 2. Plant height and collar diameter of Australian cedar at 126, 171, 219, 305 and 379 days after transplanting as a function of the $\mathrm{N}$ doses applied on soil.

Figura 2. Altura das plantas e diâmetro de cedro-australiano aos 126, 171, 219, 305 e 379 dias após o transplante em função das doses de $\mathrm{N}$ aplicadas no solo.

Considering the last evaluation, the maximum plants height was $390 \mathrm{~cm}$, and the $\mathrm{N}$ rate related with this response was $271 \mathrm{~g}$ hole- 1 . However, for reach the maximum economic yield $(90 \%$ of maximum yield) $85 \mathrm{~g}$ of $\mathrm{N}$ was necessary. This amount represents about $30 \%$ of the rate necessary to obtain the maximum yield, indicating that applying fertilizer to attain maximum yield may be uneconomical due to high cost of fertilizer. 
Collar diameter of Australian cedar plants was influenced by $\mathrm{N}$ rates applied (Table 2). This parameter is considered the variable that best predicts production performance after transplanting in forest species (CARGNELUTTI FILHO, 2012). In the fifth and seventh assessments (305 and 379 days after transplanting), collar diameter was represented by quadratic equations (Figure 2). The larger collar diameter of Australian cedar can be related to a more developed root system, providing greater strength and efficiency in the absorption of water and nutrients (UCHIDA; CAMPOS, 2002). The maximum diameter was $67.4 \mathrm{~mm}$ at a dose of $231 \mathrm{~g}$ hole- 1 of $\mathrm{N}$ at 379 days after transplant. Considering $90 \%$ as maximum economic yield (MEY) we estimated that $75.5 \mathrm{~g}$ of $\mathrm{N}$ hole-1 can provide an approximate diameter of $60 \mathrm{~mm}$.

Nitrogen content in leaves at 305 days after transplanting did not show significant difference, so it was not possible to adjust the equations to estimate the levels of nutrients in plants as a function of $\mathrm{N}$ application in the soil (Table 2). Also, there was no correlation between $\mathrm{N}$ foliar content and $\mathrm{N}$ dose applied, or between $\mathrm{N}$ foliar content and height and collar diameter of the Australian cedar plants. However similar levels of $\mathrm{N}$ and $\mathrm{K}$ found in this study were observed by Benatti et al. (2012) in a study of Australian cedar cloned matrices. The lack of response indicate that there may have been a dilution effect of nutrients in the plant, since the species responded to $\mathrm{N}$ fertilization in height and diameter, but there was no change in nutrient concentration in shoots. The plants treated with higher doses of the nutrient developed more than those that received lower doses, thus, they stored and used more nutrients in their tissues, for this reason could not increase the leave $\mathrm{N}$ content.

One can note that plants that received higher doses of $\mathrm{N}$, presented greater height and collar diameter, also had a greater number of leaves. In addition, plants that present higher aerial part development tend to have a more efficient root system, because there is a balance between the shoot and root system (CARNEIRO et al. 2007). Thus, plants that received higher $\mathrm{N}$ doses have greater development potential, making the system more efficient.

Table 2. Nitrogen, phosphorus and potassium foliar content $\left(\mathrm{g} \mathrm{kg}^{-1}\right)$ in each one of $\mathrm{N}, \mathrm{P}$ and $\mathrm{K}$ experiments at 305 days after transplanting.

Tabela 2. Teor foliar de nitrogênio, fósforo e potássio $\left(\mathrm{g} \cdot \mathrm{kg}^{-1}\right)$ em cada um dos experimentos aos 305 dias após o transplante.

\begin{tabular}{|c|c|c|c|c|c|}
\hline $\begin{array}{l}\text { Dose } \mathrm{N} \text { applied } \\
\left(\mathrm{kg}^{-h^{-1}}\right)^{-1}\end{array}$ & $\begin{array}{l}\mathrm{N} \text { foliar }{ }^{\mathrm{ns}} \\
\left.\left(\mathrm{g}^{\mathrm{kgg}}\right)^{-1}\right)\end{array}$ & $\begin{array}{c}\text { Dose } \mathrm{P}_{2} \mathrm{O}_{5} \text { applied } \\
\left(\text { kg.ha }^{-1}\right)\end{array}$ & $\begin{array}{l}\text { P foliar }{ }^{\text {ns }} \\
\left(\text { g.kg }^{-1}\right)\end{array}$ & $\begin{array}{c}\text { Dose } \mathrm{K}_{2} \mathrm{O} \text { applied } \\
\left(\mathrm{kg.ha}^{-1}\right)\end{array}$ & $\begin{array}{l}\text { K foliar }{ }^{\text {ns }} \\
\left(\text { g.kg }^{-1}\right)\end{array}$ \\
\hline 0 & 30.8 & 0 & 2.0 & 0 & 51.1 \\
\hline 31 & 32.3 & 31 & 1.9 & 16 & 48.6 \\
\hline 63 & 30.9 & 63 & 2.0 & 31 & 45.8 \\
\hline 125 & 34.1 & 125 & 1.6 & 63 & 52.4 \\
\hline 250 & 29.0 & 250 & 1.8 & 125 & - \\
\hline
\end{tabular}

Being a deciduous species, after leaves and twigs fall, it occurs tissues mineralization and consequently, nitrogen cycling and other nutrients that can be still present in the organs (JUNIO et al. 2012). The mineralized nitrogen, together with that stored by the plant, can contribute to the maintenance of higher diameter and height growth rates, especially in treatments with higher doses of the element.

Nitrogen supply influenced the development of leaf tissues. It was found that treatments with nitrogen, compared to those without nitrogen fertilization, decreased the thickness of the abaxial and adaxial epidermis (Figure 3), and palisade and spongy parenchyma that comprise the mesophyll, resulting in lower leaf thickness.

The reduction in leaf thickness, of the palisade parenchyma in particular, with the application of nitrogen, until the dose considered optimal, has been observed in other species, such as Panicum maximum and Eucalyptus grandis (GRASSI et al. 2002), and associated with an increase in leaf area in response to nitrogen.

Nitrogen fertilization promoted greater differentiation between palisade and spongy parenchyma, which apparently had a smaller volume of intercellular space and an increase in the number of chloroplasts in the cells. The more irregular shape of parenchyma cells of plants receiving nitrogen fertilizer probably is associated with starch accumulation in the chloroplasts. 


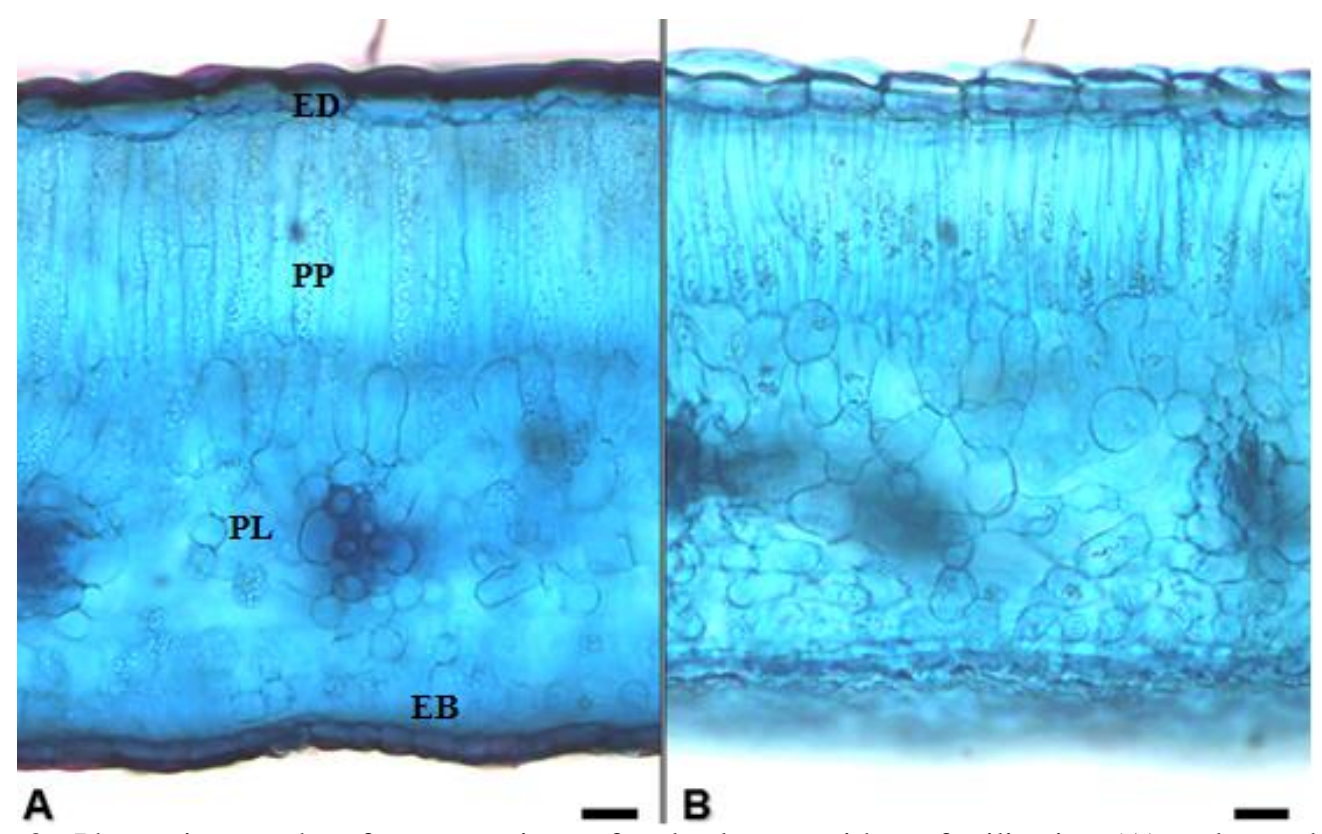

Figure 3. Photomicrographs of cross-sections of cedar leaves without fertilization (A) and at a dose of $252 \mathrm{~g}$ of $\mathrm{N}^{\text {hole }}{ }^{-1}$ (B). ED: adaxial epidermis; PP: palisade parenchyma; PL: Spongy parenchyma; EB: abaxial epidermis. Bar: $20 \mu \mathrm{m}$.

Figura 3. Fotomicrografias de secções transversais de folhas de cedro sem adubação (A) e com uma dose de $252 \mathrm{~g}$ de N.cova ${ }^{-1}$ (B). ED: epiderme adaxial; PP: parênquima paliçádico; PL: parênquima esponjoso; EB: epiderme abaxial. Barra: $20 \mu \mathrm{m}$.

The reduction in optimal nitrogen content results, in general, in the development of xeromorphic characteristics in the leaves, such as increased trichome density, thickening of the cuticle and multiple layers of the palisade parenchyma (SILVA et al. 2011). In general, the results show that nitrogen fertilization can modify the development of Australian cedar leaves, providing anatomical changes that increase the photosynthetic capacity of plants.

The midribs of leaves with and without fertilization showed no structural differences in vascular tissue; however leaves without fertilization showed signs of tissue disorganization and less tissue differentiation, when compared to plants that received nitrogen (Figure 4). The nitrogen application also reduced the width of the leaf midrib (Figure 4A and 4B). The increase width of the midrib of leaves without fertilization may be related mainly to the higher number of parenchyma cells located in the upper portion of the rib vascular bundle (Figure 4C and 4D).

On the other hand, the plants treated with nitrogen showed higher thickening of the collenchyma and parenchyma cell walls (Figure 4E and 4F), most likely associated with an increase in biomass production. In addition, thicker cell walls and higher degree of lignification are physical barriers to the penetration of pathogens and often result in major structural resistance to plant diseases (SANTOS et al. 2010; CARRÉ-MISSIO et al. 2012).

\section{Experiment with phosphorus doses}

Phosphorus application using simple superphosphate influenced the height and collar diameter development of Australian cedar. Regarding plants height, there was no significant difference at the first, second and third assessments (60,80 and 126 days after transplanting). From the 4th evaluation realized at 171 days after transplant, it was possible to detect a difference in height to response $\mathrm{P}$ doses. There was a linear response in height and diameter to phosphate fertilizer application in the assessments performed at 171, 219 and 305 days after transplant (Figure 5).

The linear increase, both in height and diameter until 305 days after transplant, indicates that species is quite exigent about the soil phosphorus availability. Also, another factor that contributed to linear response was the initial phosphorus availability in the soil, since it was considered too low by the criteria established by Minas Gerais State Soil Fertility Commission (ALVAREZ et al. 1999). 


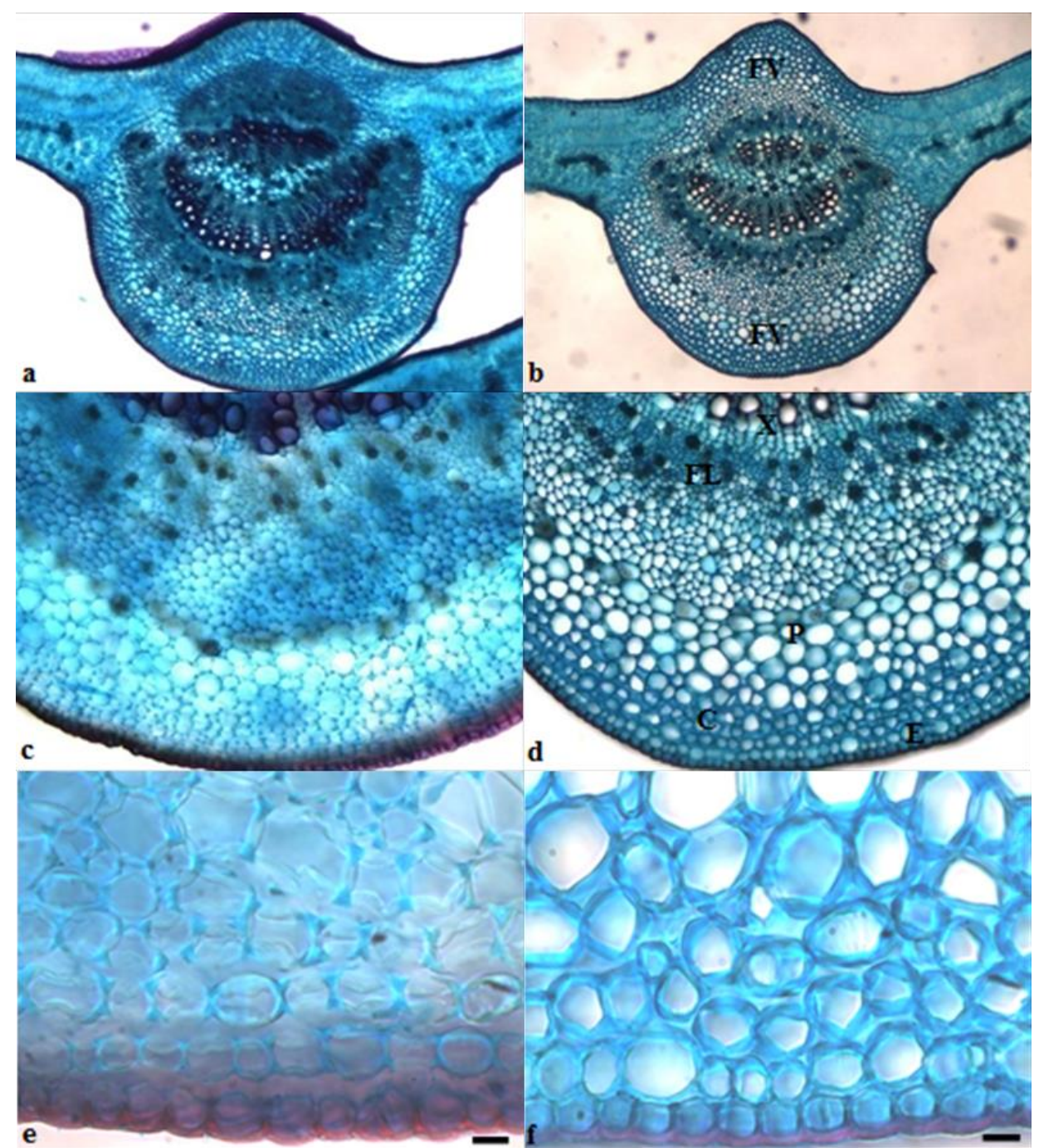

Figure 4. Photomicrographs of cross-sections of the midrib (A and B) and vascular tissue details of cedar leaves without nitrogen fertilization (A, C and E) and the application of $252 \mathrm{~g}$ of $\mathrm{N} \mathrm{hole}^{-1}$ (B, D, and F). FV: Vascular bundle; X: Xylem; FL: Phloem; P: Parenchyma; C: Collenchyma; E: Epidermis. Bars: $20 \mu \mathrm{m}(\mathrm{C}, \mathrm{D}, \mathrm{E}, \mathrm{F})$ and $200 \mu \mathrm{m}$ (A and B).

Figura 4. Fotomicrografias de secções transversais da nervura central (A e B) e detalhes de tecidos vasculares da folha do cedro sem adubação nitrogenada (A, C e E) e da aplicação de $252 \mathrm{~g}$ de N. $\operatorname{cova}^{-1}$ (B, D e F). FV: feixe vascular; X: Xilema; FL: Floema; P: Parênquima; C: Colênquima; E: Epiderme. Barras: $20 \mu \mathrm{m}$ (C, D, E, F) e $200 \mu \mathrm{m}$ (A e B).

For the evaluation performed at 379 days after transplant, the quadratic model was selected to represent the development of Australian cedar plant height (Figure 5).

There was no difference in height and collar diameter of the plants receiving the two highest doses of phosphorus (125 and $250 \mathrm{~g}$ of P2O5 per plant), indicating that nutrients content in the plant were not limiting from $125 \mathrm{~g}$ P2O5 per plant.

The dose that resulted in the largest growth in height was $219 \mathrm{~g}$ hole-1, whose plants reached $414 \mathrm{~cm}$ at 379 days. The response to height observed in this present study corroborate that noticed by Fontes et al. (2013), who found linear response to the growing supply of P2O5, despite the regression model in the present study at 379 days has been quadratic.

FLORESTA, Curitiba, PR, v. 45, n. 3, p. 599 - 608, jul. / set. 2015.

Moretti, B. da S. et al.

ISSN eletrônico 1982-4688 / ISSN impresso 0015-3826 

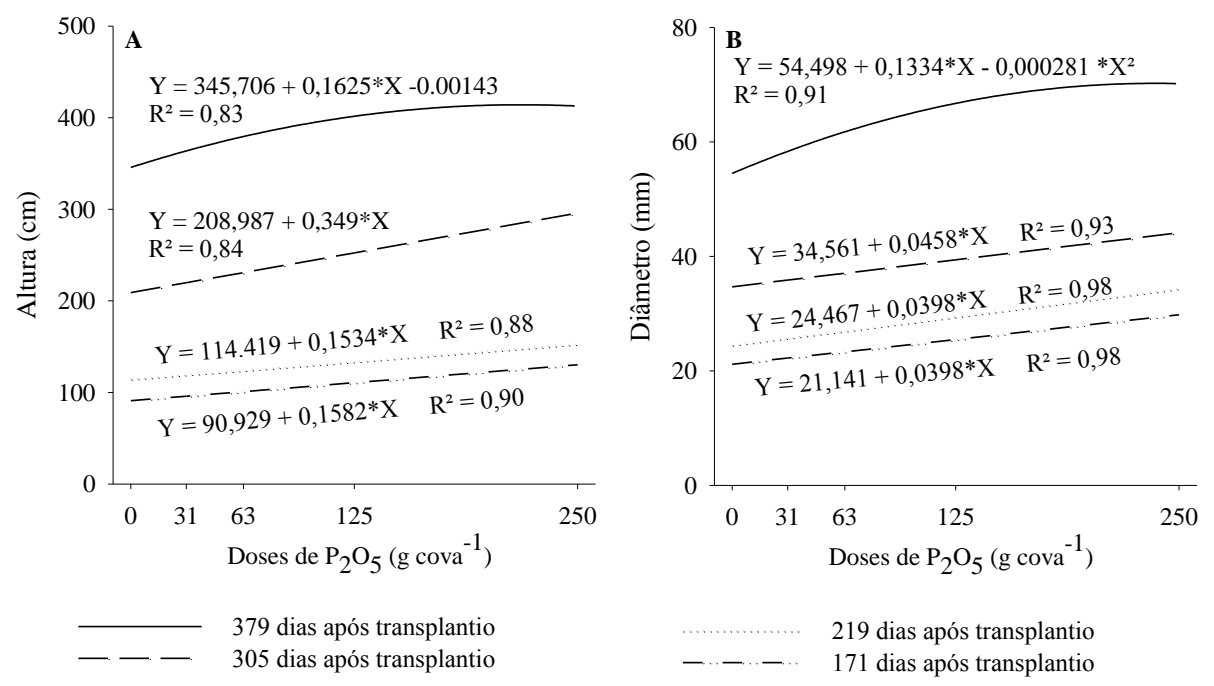

Figure 5. Plant height (A) and collar diameter (B) of Australian cedar at 171, 219, 305 and 379 days after transplanting as a function of $\mathrm{P}_{2} \mathrm{O}_{5}$ doses.

Figura 5. Altura das plantas (A) e diâmetro (B) de cedro-australiano aos 171, 219, 305 e 379 dias após o transplante em função de doses de $\mathrm{P}_{2} \mathrm{O}_{5}$.

According to quadratic regression model (Figure 5), a dose of $\mathrm{P} 2 \mathrm{O} 5$ that provided the maximum collar diameter development of the plants at 379 days was $237 \mathrm{~g}$ hole- 1 , which gave a diameter of $70 \mathrm{~mm}$. Thus, considering plants height, $80 \mathrm{~g}$ hole-1 of P2O5 (diameter $63 \mathrm{~mm}$ ) was enough to provide the maximum economic yield (MEY) in the initial stage of Australian cedar crop in Campo Belo, MG.

On average, the height plants grew up in $1 / 3$ from their size observed at final assessment in the first half of the experimental period, and $2 / 3$ in the second half. The growth in diameter was slightly more uniform over time; however, both the height and the collar diameter had reduced growth rates in periods of low water availability. It was noticed that until 3 months after phosphate fertilizer application Australian cedar seedlings had low response to phosphorus application, it can be a indicating that the species spend determined time between phosphate fertilizer application and increase of the rate growth. This time seems to be bigger than other tree species, such as eucalyptus. Likely, it can be a genetic trait of the species, however, subject to selection through genetic improvement and environmental condition, as water availability. In addition, we presume that the uniform distribution of the phosphorus fertilizer on the soil throughout in the planting hole can decrease response time to height and diameter plants growth.

Although the treatments provided the difference in the growth of Australian cedar, the phosphorus concentration in the leaf were not affected by the rates of $\mathrm{P} 2 \mathrm{O} 5$ applied to the soil (Table 2). Note that plants receiving higher doses of $\mathrm{P} 2 \mathrm{O} 5$ had more vigorous growth, hence larger amount of the nutrient is absorbed, but this was not expressed as enhanced content in the leaves.

\section{Experiment with different potassium doses}

Height and diameter of Australian cedar seedlings subjected to different doses of potassium are presented in table 3. Australian cedar seedlings did not respond to application of potassium in the soil during in this study, likely, it is due to the high initial concentration of potassium (117 mg dm-3) in soil (Table 1) (ALVAREZ, 1999). Other studies have also found similar responses, for instance, Gava (2013) studied the development of eucalyptus in response to increasing doses of $\mathrm{K} 2 \mathrm{O}$. The author tested doses ranging from 0 to $360 \mathrm{~kg} \mathrm{~K} 2 \mathrm{O}$ ha- 1 and did not observe significant difference in the height and diameter production variables, assessed at 5 years of age. The result was attributed to the initial content of exchangeable potassium in the soil of $65 \mathrm{mg} \mathrm{dm}-3$. Silva (1996) also observed no effect of potassium fertilization on the dry matter production of the aerial part, root and total dry matter of various native species, also attributing this result to the $\mathrm{K}$ content in the soil. 
The high initial soil $\mathrm{K}$ content was due to the land use history, because for several years, the experimental area was used as a coffee plantation, which received constant maintenance fertilization. After removing the coffee, the Australian cedar experiment was implanted, thus, the plants had benefited from the residual effect of the previous crop.

Table 3. Plants height and collar diameter of Australian cedar from 60 to 379 days after seedling transplanting as a function of the $\mathrm{K}_{2} \mathrm{O}$ rate applied per hole.

Tabela 3. Altura e diâmetro do cedro australiano de 60 a 379 dias após o transplante das mudas em função da dose de $\mathrm{K}_{2} \mathrm{O}$ aplicada por cova.

\begin{tabular}{|c|c|c|c|c|c|c|c|c|}
\hline & \multirow{2}{*}{$\begin{array}{c}\mathrm{K}_{2} \mathrm{O}(\mathrm{g}) \\
\text { Dose }\end{array}$} & 60 dat $^{\text {ns }}$ & 80 dat $^{\text {ns }}$ & 125 dat $^{\mathrm{ns}}$ & 171 dat $^{\text {ns }}$ & 219 dat $^{\text {ns }}$ & 305 dat $^{\text {ns }}$ & 379 dat $^{\text {ns }}$ \\
\hline & & \multicolumn{7}{|c|}{$\mathbf{c m}$} \\
\hline \multirow{7}{*}{ 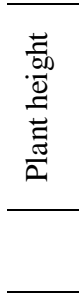 } & 0 & 27.8 & 34.2 & 50.0 & 53.8 & 68.6 & 109.3 & 215.1 \\
\hline & 16 & 25.4 & 41.9 & 55.3 & 59.8 & 76.9 & 108.9 & 201.4 \\
\hline & 31 & 26.6 & 39.8 & 58.8 & 62.7 & 78.1 & 114.8 & 224.8 \\
\hline & 63 & 28.3 & 43.5 & 63.0 & 68.0 & 87.8 & 122.7 & 228.6 \\
\hline & 125 & 36.2 & 55.8 & 70.1 & 72.1 & 93.8 & 125.9 & 223.9 \\
\hline & $\mathrm{K}_{2} \mathrm{O}(\mathrm{g})$ & 60 dat $^{\text {ns }}$ & 80 dat $^{\text {ns }}$ & 125dat ${ }^{\mathrm{ns}}$ & 171 dat $^{\text {ns }}$ & 219 dat $^{\mathrm{ns}}$ & 305 dat $^{\text {ns }}$ & 379 dat $^{\text {ns }}$ \\
\hline & Dose & \multicolumn{7}{|c|}{$\mathrm{mm}$} \\
\hline \multirow{5}{*}{ 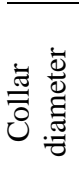 } & 0 & 7.2 & 9.1 & 14.0 & 15.5 & 16.6 & 22.8 & 36,7 \\
\hline & 16 & 7.1 & 9.6 & 14.5 & 16.4 & 17.9 & 23.2 & 37,1 \\
\hline & 31 & 6.9 & 9.5 & 15.4 & 17.5 & 19.7 & 24.6 & 39,1 \\
\hline & 63 & 8.2 & 10.0 & 16.5 & 18.5 & 20.1 & 25.4 & 35,4 \\
\hline & 125 & 9.3 & 12.5 & 18.0 & 19.5 & 21.1 & 25.7 & 38,7 \\
\hline
\end{tabular}

dat: Days after transplanting; ${ }^{\text {ns }}$ : not significant by $\mathrm{F}$ test at $5 \%$ probability.

Another factor that may have contributed to the low response of the Australian cedar to potassium application is the plant genetic itself. This species may be undemanding in potassium or have a higher absorption efficiency degree of this nutrient.

As for the potassium content in the leaves of Australian cedar at the end of the experimental period, there was no influence of the treatments (Table 2), confirming the considerations regarding the historical use of the area.

\section{CONCLUSIONS}

- The maximum economic yield to Australian cedar crops in the region of Campo Belo, MG was achieved by providing of $75 \mathrm{~g}$ of $\mathrm{N}$ and $80 \mathrm{~g}$ hole- 1 of P2O5. For potassium, it was not possible to establish the dose that allows maximum economic efficiency. Therefore, the initial concentration of $\mathrm{K}$ in the soil of around $100 \mathrm{mg} \mathrm{dm}-3$ seems adequate to meet the nutritional needs of the species.

- Foliar concentrations did not vary with the levels of N, P2O5 and K2O applied to the soil. The concentration of N, P and $\mathrm{K}$ in Australian cedar leaves were 30, 18 and $2 \mathrm{mg} \mathrm{kg}-1$, respectively.

- The supply of N, P and K influenced the growth in height and diameter of Australian cedar seedlings mainly in the months of higher soil water availability.

\section{ACKNOWLEDGMENT}

The authors thank the following institutions for their support: Federal University of Lavras; CAPES; CNPq, FAPEMIG and Forest Nursery Bela Vista

\section{REFERENCES}

ALVAREZ, V. V. H.; NOVAIS, R. F; BARROS, N. F.; CANTARUTTI, R. B.; LOPES, A. S. Interpretação dos resultados das análises de solos. In: RIBEIRO, A. C.; GUIMARÃES, P. T. G.; ALVAREZ, V. V. H. (Eds.). Recomendações para o uso de corretivos e fertilizantes em Minas Gerais: 5. Aproximação. Viçosa, MG. 1999. p. 25 - 32. 
BENATTI, B. P.; FURTINI NETO, A. E.; MORETTI, B. S.; STEHLinG, E. C.; SOUSA, T. M. A. Desenvolvimento de matrizes clonais de cedro australiano em diferentes substratos sob doses de fertilizantes. Ciência e Agrotecnologia, v. 36, n. 3, p. 285 - 293, 2012.

CARGNELUTTI FILHO, A.; ARAÚJO, M. M.; GASPARIN, E.; ÁVILA, A. L. O tamanho da amostra para avaliar a altura e o diâmetro de mudas de Cabralea canjerana. Ciência Rural, v. 42, n. 7, p. 1204 $1211,2012$.

CARNEIRO, J. G. A.; BARROSO, D. G.; SOARES, L. M. S. Crescimento de mudas em raiz nua de Pinus taeda L. sob cinco espaçamentos no viveiro e seu desenvolvimento no campo. Revista Brasileira de Agrociência, v. 13, n. 3, p. 305 - 310, 2007.

CARRÉ-MISSIO, V.; RODRIGUES, F. A.; SCHURT, D. A.; MOREIRA, W. R.; REZENDE, D. C.; KORNDÖRFER, G. H.; ZAMBOLIM, L. Proteção local, não sistêmica, do silicato de potássio reduz os sintomas da ferrugem do cafeeiro. Tropical Plant Pathology, v. 37, n. 4, p. 275 - 280, 2012.

FERREIRA, D. F. Sisvar: um sistema computacional de análise estatística. Ciência e Agrotecnologia, v. 35, n. 6, p. 1039 - 1042, 2011.

FONTES, A. G.; ROGRIGUES, A. C. G.; RODRIGUES, E. F. G. Eficiência nutricional de espécies arbóreas em função da fertilização fosfatada. Pesquisa Florestal Brasileira. Colombo. v. 33, n. 73, p. $09-18,2013$.

GAVA, J. L. Efeito da adubação potássica em plantios de E. grandis conduzidos em segunda rotação em solos com diferentes teores de potássio trocável. Instituto de Pesquisas e Estudos Florestais. 1997. Disponível em: <www.ipef.br/publicacoes/stecnica/nr30/cap8.pdf〉. Acesso em 17 de setembro, 2013.

GRASSI, G.; MEIR, P.; CROMER, R.; TOMPKINS, D.; JARVIS, P. G. Parâmetros fotossintéticos em mudas de Eucalyptus grandis em função da taxa de fornecimento de nitrogênio. Plant Cell Environ, v. 25, n. 1, p. 1677 - 1688, 2002.

JUNIO, G. R. Z.; SAMPAIO, R. A.; PRATES, F. B. S.; FERNANDES, L. A.; NASCIMENTO, A. L. Crescimento de cedro e leguminosas arbóreas em áreas degradadas, adubadas com pó-de-rocha. Revista Caatinga, Mossoró. v. 25, n. 2, p. 159 - 165, 2012.

LOPES, A. S.; GUILHERME, L. R. G. Uso eficiente de fertilizantes e corretivos agrícolas: aspectos agronômicos. ANDA. 3. ed. São Paulo. 72 p. 2000.

MAlavolta, E.; VITTI, G. C.; OliveirA, S. A. Avaliação do estado nutricional das plantas: princípios e aplicações. Piracicaba: Potafos, 1997. 319 p.

SANTANA, R. C.; BARROS, N. F.; NOVAIS, R. F.; LEITE, H. G.; COMERFORD, N. B. Alocação de nutrientes em plantios de eucalipto no Brasil. Revista Brasileira de Ciência do Solo, v. 32, n. especial, p. $2723-2733,2008$.

SANTOS, M. E. R.; FONSECA, D. M.; BALBINO, E. M.; SILVA, S. P.; MONNERAT, J. P. I. S. Valor nutritivo de perfilhos e componentes morfológicos em pastos de capim-braquiária diferidos e adubados com nitrogênio. Revista Brasileira de Zootecnia, v. 39, n. 9, p. 1919 - 1927, 2010.

SILVA, F. C. Manual de análises químicas de solos, plantas e fertilizantes. Embrapa. 2. ed. Brasília, DF: Embrapa Informação Tecnológica. 627 p. 2009.

SILVA, G. F.; FONTES, P. C. R.; LIMA, L. P. F.; ARAÚJO, T. O.; SILVA, L. F. Aspectos morfoanatômicos de plantas de pepino (Cucumis sativus L.) sob omissão de nutrientes. Revista Verde, v. 6 , n. 2, p. 13 - 20, 2011.

SILVA, I. R.; FURTINI NETO, A. E.; VALE, F. R do; CURI, N. Absorção de nutrientes em espécies florestais sob influência da adubação potássica. Revista do Instituto Florestal, v. 8, n. 2, p. 99 - 108 , 1996.

TUCCI, C. A. F.; LIMA, H. N.; LESSA, J. F. Adubação nitrogenada na produção de mudas de mogno (Swietenia macrophylla King). Acta Amazônica, v. 39, n. 2, p. 289 - 294, 2009.

UCHIDA, T.; CAMPOS, M. A. A. Influência do sombreamento no crescimento de mudas de três espécies amazônicas. Pesquisa Agropecuária Brasileira, v. 37, n. 3, p. 281 - 288, 2002. 